\title{
PENGARUH KEPRIBADIAN, ORIENTASI KERJA DAN PENEMPATAN PEGAWAI TERHADAP KINERJA KARYAWAN PT. ADVANTAGE SUPPLY CHAIN MANAGEMENT (SCM) CABANG BATAM
}

\author{
mira yona ${ }^{1)}$, della yulita ${ }^{2)}$ \\ Prodi Manajemen, Fakultas Ekonomi, Universitas Riau kepulauan \\ Mirayona@yahoo.co.id ${ }^{1)}$ \\ Prodi Manajemen, Fakultas Ekonomi, Universitas Riau kepulauan \\ Cutdellayulita05@gmail.com²)
}

\begin{abstract}
The purpose of this study was to determine the effect of variable personality, work orientation and employee placement partially and simultaneously on the performance of employees of PT. Advantage Supply Chain Management (SCM) Batam Branch. The population in this study were employees of PT. The Advantage Supply Chain Management (SCM) of the Batam Branch, which numbered 80 people with members of the population, was sampled as a whole by the questionnaire method. The results of this study are multiple linear regression analysis. Based on the results of the study it can be concluded that (1) personality influences employee performance seen from a significant value of 0,000 <0,05 and the value of t count 12,393>t table 1,991. (2) work orientation has an effect on employee performance seen from significant value 0,000<0,05 and t count value 6,282. (3) employee placement has no effect on employee performance seen from a significant value of 0.689>0.05 and t count value of $0.402<t$ table 1.991. (4) the results of the study simultaneously show that personality, work orientation and employee placement have an influence on the performance of the Batam Branch Advantage Supply Chain Management (SCM) employees. This can be seen from the results of the $F$ test where the significance value is $0,000<0,05$ and the calculated $F$ value is 122,781> F table 2,72.
\end{abstract}

Keywords: personality, work orientation, employee placement and employee performance

\begin{abstract}
ABSTRAK
Tujuan dari penelitian ini adalah untuk mengetahui pengaruh variabel kepribadian, orientasi kerja dan penempatan pegawai secara parsial dan simultan terhadap kinerja karyawan PT. Advantage Supply Chain Management (SCM) Cabang Batam. Populasi dalam penelitian ini adalah karyawan PT. Advantage Supply Chain Management (SCM) Cabang Batam yang berjumlah 80 orang dengan anggota populasi dijadikan sampel secara keseluruhan dengan metode kuesioner.

Hasil penelitian ini dengan analisis regresi linear berganda. Berdasarkan hasil penelitian dapat disimpulkan bahwa (1) kepribadian berpengaruh terhadap kinerja karyawan dilihat dari nilai signifikan 0,000 $<0,05$ dan nilai t hitung 12,393 $>\mathrm{t}$ tabel 1,991. (2) orientasi kerja berpengaruh terhadap kinerja karyawan dilihat dari
\end{abstract}


nilai signifikan $0,000<0,05$ dan nilai t hitung 6,282. (3) penempatan pegawai tidak berpengaruh terhadap kinerja karyawan dilihat dari nilai signifikan 0,689 > 0,05 dan nilai t hitung $0,402<\mathrm{t}$ tabel 1,991. (4) hasil penelitian secara simultan menujukkan bahwa kepribadian, orientasi kerja dan penempatan pegawai berpengaruh bersama-sama terhadap kinerja karyawan PT Advantage Supply Chain Management (SCM) Cabang Batam. Hal tersebut dapat dilihat dari hasil uji $\mathrm{F}$ dimana nilai signifikansi sebesar $0,000<0,05$ dan nilai $\mathrm{F}$ hitung $122,781>\mathrm{F}$ tabel 2,72.

\section{Kata kunci : kepribadian, orientasi kerja, penempatan pegawai dan kinerja karyawan}

\section{PENDAHULUAN}

PT. Advantage Supply Chain Management (SCM) adalah Perusahaan Swasta Nasional yang bergerak dalam jasa cash management. Berdiri Sejak tanggal 02 November 2004, PT. Advantage SCM memiliki 33 kantor cabang yang terletak di seluruh Indonesia salah satunya di Kepulauan Riau Kota Batam yang beralamat di Komplek Rosedale Blok E 87-88, Batam Centre, Kota Batam. PT. Advantage SCM membantu industri perbankan dalam mengurangi biaya operasional, mencegah duplikasi dan beban kerja serta meningkatkan produktifitas, menjaga kerahasiaan dan keamanan di dalam operasional perbankan. Sistem kerja yang dilakukan pada PT. Advantage SCM Cabang Batam dilakukan sesuai dengan SOP (Standar Operasional Prosedur) yang ada di perusahaan. Sesuai dengan tingkat kebutuhan pekerjaan, terkadang karyawan dituntut untuk bekerja dengan loyalitas yang artinya adanya sistem lembur dan kerja shift. Dengan adanya hal tersebut sering terjadi permasalahan-permasalahan yang timbul karena konflik intern dari diri karyawan itu sendiri, contohnya adanya perilaku pemalas, komitmen kurang, emosional, kedisiplinan tidak terkendali, kerap bolos kerja, dan egoistis dalam bekerjasama. Maupun konflik eksternal dengan rekan kerja atau teman sejawat yaitu adanya perbedaan pendidikan, usia, pengalaman kerja, sikap, dan ketrampilan.

Meningkatnya persaingan profesionalisme dalam dunia pekerjaan dan ilmu pengetahuan yang luas pada PT. Advantage SCM Cabang Batam menuntut setiap karyawan memiliki kepribadian yang mantap dan rasa percaya diri yang tinggi guna menunjang keberhasilan dalam pekerjaan. PT. Advantage SCM Cabang Batam memiliki 80 karyawan dengan berbagai karakter dan kepribadian yang berbeda-beda. Dengan demikian Manajemen Sumber Daya Manusia selalu memberikan arahan dan mengingatkan jika ada karyawan yang salah dalam melakukan pekerjaan atau tidak sesuai dengan SOP perusahaan.

Kepribadian merupakan faktor penting dalam meningkatkan kinerja perusahaan, faktor lain yang dapat meningkatkan kinerja kerja pada PT. Advantage SCM Cabang Batam adalah dengan pemberian 
orientasi kerja karyawan dan penempatan kerja sesuai dengan tingkat kebutuhan dan pengalaman kerja kayawan. Pada PT. Advantage SCM Cabang Batam orientasi kerja yang dilakukan sebatas kepada karyawan yang baru diterima di PT. Advantage SCM Cabang Batam sebagai pengenalan kepada bidang pekerjaan, lingkungan kerja dan karyawan lainnya, orientasi kerja yang dilakukan selama tiga bulan sesuai dengan masa percobaan kerja kepada karyawan baru.

Orientasi kerja awalnya dilakukan oleh Manajemen Sumber Daya Manusia yaitu memberikan pengenalan tentang lingkungan perusahaan, karyawan lainnya dan job description yang dilakukan yang selanjutnya diserah terimakan kepada kepala divisi yang bertanggung jawab terhadap kebutuhan karyawan, sebagai pengenalan terhadap cara kerja karyawan baru tersebut.

Masa orientasi kerja yang dilakukan oleh PT. Advantage SCM Cabang Batam sebagai penilaian untuk kedepannya bagi penilaian kinerja pada posisi penempatan kerja yang akan diberikan. Kedua hal tersebut saling terpaut satu dengan lainnya, jika pada masa orientasi kerja karyawan baru tersebut melakukan pekerjaan dengan baik dan menjalankan sesuai SOP perusahaan, maka untuk melakukan penempatan kerja kepada karyawan tersebut akan berjalan dengan baik.

Penempatan kerja yang dilakukan pada PT. Advantage SCM Cabang Batam dilihat berdasarkan penilaian pada saat masa orientasi kerja sesuai dengan prestasi akademis, pengetahuan, ketrampilan kerja selama masa orientasi kerja dan pengalaman yang dimiliki oleh karyawan tersebut. Ketika kinerja kerja yang dilakukan baik maka tujuan dari organisasi dalam meningkatkan keuntungan berjalan dengan baik. Pada PT. Advantage SCM Cabang Batam hasil kinerja karyawan menjadi peran penting dalam menilai karyawan dalam melakukan pekerjaan yang dilakukannya.

Ketika kinerja kerja yang dilakukan baik maka tujuan dari organisasi dalam meningkatkan keuntungan berjalan dengan baik. Dimasa depan kinerja kerja karyawan akan mempengaruhi kualitas perusahaan, karena karyawan merupakan aset terbesar bagi perusahaan tersebut. Pada PT. Advantage SCM Cabang Batam hasil kinerja karyawan menjadi peran penting dalam menilai karyawan dalam melakukan pekerjaan yang dilakukannya. Hal ini berkaitan dengan hubungan kerja karyawan (kontrak kerja), penggajian serta kenaikan jabatan bagi karyawan. Jika dengan adanya permasalahan yang terjadi dari kepribadian, orientasi kerja dan penempatan pegawai maka hasil kinerja karyawan menjadi menurun dan tujuan perusahaan tidak tercapai, untuk itu akan merugikan karyawan dan juga perusahaan.

Sesuai dengan penjelasan latar belakang permasalahan pada PT. Advantage SCM Cabang Batam diatas, maka peneliti tertarik untuk melakukan penelitian terhadap judul "Pengaruh Kepribadian, Orientasi Kerja, dan Penempatan Pegawai Terhadap Kinerja Karyawan Di PT. Advantage Supply Chain Management (SCM) Cabang Batam"

\section{TELAAH PUSTAKA}

\section{Kepribadian}


Kepribadian merupakan organisasi dinamik dari sistemsistem psikologis dalam individu yang menentukan kemampuan seseorang beradaptasi secara unik dilingkungannya. Kemampuan beradaptasi masing-masing individu tidak sama antara satu dengan yang lainnya, tergantung dari jenis kepribadian yang dimilikinya. Hasil akhir dari kemampuan adaptasi ini akan terlihat pada kinerja sebagai wujud tanggung jawab.

Menurut Robbins dan Judge (2008) dalam Setyarini (2017), kepribadian setiap individu akan membentuk perilaku individu. Hasil penelitian Brickell et al., dalam Setyarini (2017), menyatakan perbedaan kepribadian dari para anggota dalam tim memiliki potensi untuk meningkatkan efektivitas tim.

Menurut IK. Sihombing (2017), pengembangan kepribadian memberikan peran yang sangat besar kepada kita dalam rangka meningkatkan kualitas diri pribadi, kualitas hubungan dan kualitas kepribadian sehari-hari dan akan memberikan dorongan kepada kita untuk mengembangkan kepribadian kearah yang lebih baik. Menurut Robbins dan Judge (2008) dalam Setyarini (2017), menyebutkan kepribadian manusia secara umum ditentukan oleh beberapa faktor berikut :

\section{Keturunan}

Keturunan merujuk pada faktorfaktor yang ditentukan sejak lahir.

2. Lingkungan

Faktor lingkungan merujuk pada kebudayaan tempat kita dibesarkan, pengkondisian awal kita, norma ditengah keluarga, teman dan kelompok sosial dan pengaruh-pengaruh yang dialami.
Kepribadian individu, walaupun umumnya stabil dan konsisten, berubah dalam situasi-situasi yang berbeda.

Berdasarkan

model

kepribadian lima besar mengemukan lima dimensi dasar yang mendasari semua yang lainnya dan mencakup hampir semua variasi signifikan dalam kepribadian manusia. Skor tes dari karakteristik-karakteritik ini sangat baik untuk memprediksi bagaimana orang berperilaku dalam berbagai situasi kehidupan nyata yang dipelopori oleh Allport dan Cattell (dalam Robbins dan Judge, 2013). Model lima besar tersebut meliputi :

1. Ektraversion (extraversion). Dimensi kepribadian orang yang menjelaskan seseorang yang mampu bersosialisasi, ekspresif, dan percaya diri.

2. Keramahan (agreeables) sebuah dimensi kerpibadian yang menjelaskan seseorang yang baik, kooperatif, dan mempercayai.

3. Kehati-hatian (cocscientiousness) sebuah dimensi kepribadian yang menjelaskan seseorang yang bertanggung jawab, dapat diandalkan, persisten, dan teratur.

4. Stabilitas emosional (emosional stability) sebuah dimensi kepribadian yang menunjukkan bahwa seseorang yang mampu mengelola respon emosional.

5. Keterbukaan terhadap pengalaman (openess to experience) sebuah dimensi kepribadian yang mengarakterisasi seseorang dari sisi imajinasi, sensitivitas, dan rasa ingin tahu.

\section{Orientasi Kerja}

3. Situasi 
Menurut Sunyoto (2012), menyatakan orientasi merupakan suatu program untuk memperkenalkan pegawai baru pada peran-peran mereka, organisasi, kebijakan-kebijakannya, nilai-nilai, keyakinan-keyakinan dan pada rekan kerja mereka. Menurut Ardana, dkk dalam Setyarini (2017), menyatakan orientasi merupakan kegiatan yang dilaksanakan dengan maksud untuk memperkenalkan tenaga kerja baru dengan tenaga kerja lama atau manajemen secara menyeluruh sesuai dengan hierarki perusahaan.

Menurut Smalley (2010) orientasi karyawan baru salah satu peran penting dalam mengarahkan orang-orang yang direkrut, pada masa orientasi membentuk kesan pertama pada karyawan baru sehingga mempengaruhi sikap karyawan. Dari definisi tersebut dapat disimpulkan bahwa orientasi adalah pengenalan dan adaptasi terhadap suatu situasi atau lingkungan.

Tujuan orientasi menurut Smith dalam Marwansyah, (2009) sebagai berikut:

1. Pengenalan organisasi atau perusahan

2. Penyampaian kebijakan dan praktik-praktik yang penting

3. Penyampaian informasi tentang benefits dan services

4. Pendaftaran program benefit

5. Pengisian dokumen-dokumen kepegawaian

6. Penyampaian informasi tentang harapan-harapan manajemen

7. Penetapan harapan-harapan atau tujuan pegawai

8. Pengenalan rekan-rekan kerja

9. Pengenalan fasilitas kerja

10. Pengenalan tugas-tugas atau pekerjaan
Menurut Sunyoto (2012) yang menjadi indikator dalam kegiatan orientasi kerja adalah sebagai berikut:

1. Hubungan dengan rekan kerja

2. Pengenalan Perusahaan

3. Solidaristik

4. Komunikasi

5. Program Orientasi

6. Sosialisasi

\section{Penempatan Pegawai}

Menurut Ardana dalam Muaja, dkk (2017), penempatan merupakan pencocokan atau membandingkan kualifikasi yang dimiliki dengan persyaratan pekerjaan dan sekaligus memberikan tugas, pekerjaan kepada calon karyawan untuk dilaksanakan. Penempatan kerja berarti mengalokasikan pegawai pada posisi tertentu, hal ini khusus pada pegawai baru.

Menurut Siswanto dalam Hertanudin (2015), penempatan kerja merupakan suatu proses pemberian tugas dan pekerjaan kepada pegawai yang lulus dalam seleksi untuk melaksanakan tugasnya dengan kontinuitas dan tanggung jawab. Penempatan kerja pegawai berhubungan dengan berbagai kepentingan organisasi maupun kepentingan pegawai itu sendiri.

Menurut Ardana, Mujiat dan Utama (2012) dalam R. Montolalu, dkk (2016), menyatakan penempatan pegawai adalah suatu proses pemberian tugas dan pekerjaan yang lulus dalam seleksi untuk dilaksanakan secara continue dan wewenang serta tanggung jawab yang melekat sebesar porsi dan komposisi yang ditetapkan serta mampu mempertanggung jawabkan segala resiko yang mungkin terjadi 
atas tugas dan pekerjaan, wewenang dan tanggung jawab tersebut. Sedangkan menurut Mathis dan Jackson dalam jurnal R. Montolalu, dkk (2016), penempatan adalah menempatkan posisi seseorang ke posisi pekerjaan yang tepat, seberapa baik seseorang cocok dengan pekerjaannya akan mempengaruhi jumlah dan kualitas pekerjaannya. Menurut Yuniarsih dan Suwatno dalam AB Rudianto (2018) ada beberapa dimensi menyangkut dimensi penempatan pegawai antara lain sebagai berikut :

1. Pendidikan

2. Pengetahuan Kerja

3. Ketrampilan Kerja

4. Pengalaman Kerja

Menurut Bambang Wahyudi dalam Yuliawati (2015) sebelum menempatkan tenaga kerja atau pegawai ditempat kerja mereka harus bekerja, perlu dipertimbangkan faktor lain :

a. Keahlian, adalah kesanggupan dan kecakapan seseorang untuk melaksanakan tugas dalam pekerjaannya.

b. Ketrampilan, adalah kemampuan dan penguasaan teknis operasional mengenai bidang tertentu, yang bersifat kekaryawanan.

c. Kualifikasi, keahlian yang diperlukan untuk menduduki suatu jabatan tertentu.

Ada beberapa indikator untuk mengukur penempatan pegawai menurut Siswanto, Suwatno dan Priansa (2011) dalam Yuliawati (2015) adalah sebagi berikut :

1. Prestasi Akademis

2. Pengetahuan

3. Ketrampilan

4. Pengalaman
Menurut Mahsun dalam R. Montolalu, dkk (2016), menyatakan kineja (performance) adalah gambaran mengenai tingkat pencapaian pelaksanaan suatu kegiatan/ program/ kebijakan dalam mewujudkan sasaran, tujuan, misi dan visi organisasi yang tertuang dalam strategic planning suatu organisasi. Sedangkan menurut Bangun (2012),

Kinerja (performance) adalah hasil pekerjaan seseorang yang dicapai berdasarkan persyaratanpersyaratan pekerjaan (job requirement). Menurut Wibowo (2007) dalam Hertanudin (2015), kinerja adalah tentang apa yang dikerjakan dan bagaimana mengerjakannya, kinerja dapat dinyatakan dalam bentuk istilah uang dan non uang. Dapat disimpulkan bahwa kinerja pegawai merupakan suatu hasil pekerjaan seseorang berdasarkan tujuan organisasi yang dapat berupa produk/ barang dan jasa.

Menurut Wibowo (2007) dalam Hertanudin (2015) tipe ukuran kinerja yang dijadikan indikator kinerja adalah sebagai berikut :

1. Produktivitas, memfokuskan pada jumlah pekerjaan yang diselesaikan dalam jangka waktu tertentu.

2. Kualitas, pada kualitas biasanya termasuk ukuran internal seperti susut, jumlah ditolak, cacat perunit, maupun ukuran eksternal seperti kepuasan pelanggan atau penilaian frekuensi.

3. Ketepatan Waktu, menyangkut persentase pengiriman dan perbaikan tepat waktu sesuai yang dijanjikan.

\section{Kinerja}


4. Cycle Time, yaitu jumlah waktu yang diperlukan untuk maju ke titik lain dalam proses

5. Pemanfaatan Sumber Daya, merupakan ukuran sumber daya yang digunakan lawan sumber daya tersebut untuk dipergunakan.

6. Biaya, ukuran biaya terutama berguna apabila dilakukan kalkulasi dalam dasar perunit.

\section{HIPOTESIS PENELITIAN}

Hipotesis penelitin ini adalah sebagai berikut :

$\mathrm{H} 1$ : Diduga kepribadian $\left(\mathrm{X}_{1}\right)$ berpengaruh terhadap kinerja karyawan (Y) di PT. Advantage Supply Chain Management (SCM) Cabang Batam.

$\mathrm{H} 2$ : Diduga orientasi kerja $\left(\mathrm{X}_{2}\right)$ berpengaruh terhadap kinerja karyawan (Y) di PT. Advantage Supply Chain Management (SCM) Cabang Batam.

H3 : Diduga penempatan pegawai $\left(\mathrm{X}_{3}\right)$ berpengaruh terhadap kinerja karyawan (Y) di PT. Advantage Supply Chain Management (SCM) Cabang Batam.

H4 : Diduga kepribadian $\left(\mathrm{X}_{1}\right)$, orientasi kerja $\left(\mathrm{X}_{2}\right)$ dan penempatan pegawai $\left(\mathrm{X}_{3}\right)$ secara bersama-sama berpengaruh terhadap kinerja karyawan (Y) di PT. Advantage Supply Chain Management (SCM)

Cabang Batam.

\section{METODE PENELITIAN}

\section{Populasi dan Sampel}

Populasi dalam penelitian ini adalah kepada karyawan di PT. Advantage Supply Chain Management (SCM) Cabang Batam yang berjumlah sebanyak 80 orang.

Pada penelitian ini teknik pengambilan sampel yang digunakan adalah teknik nonprobability sampling yaitu teknik pengambilan sampel yang tidak memberi peluang / kesempatan sama bagi setiap unsur atau anggota populasi untuk dipilih menjadi sampel. Teknik yang digunakan adalah sampling jenuh, menurut Sugiyono (2015) sampling jenuh adalah teknik penentuan sampel bila semua anggota populasi digunakan sebagai sampel dalam penelitian ini. Yaitu pada bagian divisi ATM 26 orang, divisi CDC 20 orang, divisi CPC 26 orang dan divisi Support sebanyak 8 orang.

\section{Jenis Data}

Sumber data yang digunakan dalam penelitian ini adalah data primer dan data sekunder :

1. Data Primer

Data primer diperoleh dari penyebaran kuesioner kepada karyawan di PT. Advantage Supply Chain Management (SCM) Cabang Batam.

2. Data Sekunder

Dalam penelitian ini data sekunder yang yaitu dengan wawancara dan meminta data yang berhubungan dengan penelitian kepada bagian personalia perusahaan PT. Advantage SCM Cabang Batam, seperti Standar Operasional Prosedur (SOP), jumlah data karyawan, dokumen. 


\section{Teknik Pengumpulan Data}

Menurut Sugiyono (2015) teknik pengumpulan data dapat dilakukan dengan interview (wawancara), kuisioner (angket), observasi (pengamatan) dan gabungan ketiganya. Adapun penjelasannya sebagai berikut:

1. Riset Lapangan yaitu interview (Wawancara) kepada karyawan PT. Advantage Supply Chain Management (SCM) Cabang Batam. Kuisioner (angket) dan Observasi (pengamatan)

2. Riset Pustaka

Penulis melakukan metode ini dengan mempelajari dan mengumpulkan data dari bukubuku yang penulis jadikan sebagai landasan teori untuk pembahasan selanjutnya.

\section{HASIL PENELITIAN}

\section{Uji Validitas}

\begin{tabular}{|c|c|c|c|c|}
\hline Variabel & $\begin{array}{c}\text { Butir } \\
\text { Pernyataan }\end{array}$ & Nilai r hitung & $\mathbf{r}$ tabel & Keterangan \\
\hline \multirow{4}{*}{$\begin{array}{c}\text { Kepribadian } \\
\text { (X1) }\end{array}$} & $\mathrm{X} 1.1$ & 0,723 & 0,22 & Valid \\
\cline { 2 - 5 } & $\mathrm{X} 1.2$ & 0,611 & 0,22 & Valid \\
\cline { 2 - 5 } & $\mathrm{X} 1.3$ & 0,7 & 0,22 & Valid \\
\cline { 2 - 5 } & $\mathrm{X} 1.4$ & 0,613 & 0,22 & Valid \\
\cline { 2 - 5 } & $\mathrm{X} 1.5$ & 0,695 & 0,22 & Valid \\
\hline \multirow{4}{*}{$\begin{array}{c}\text { Orientasi } \\
\text { Kerja (X2) }\end{array}$} & $\mathrm{X} 2.1$ & 0,639 & 0,22 & Valid \\
\cline { 2 - 5 } & $\mathrm{X} 2.2$ & 0,559 & 0,22 & Valid \\
\cline { 2 - 5 } & $\mathrm{X} 2.3$ & 0,593 & 0,22 & Valid \\
\cline { 2 - 5 } & $\mathrm{X} 2.4$ & 0,453 & 0,22 & Valid \\
\cline { 2 - 5 } & $\mathrm{X} 2.5$ & 0,64 & 0,22 & Valid \\
\hline \multirow{4}{*}{ Penempatan } & $\mathrm{X} 2.6$ & 0,676 & 0,22 & Valid \\
\cline { 2 - 5 } (X3) & $\mathrm{X} 3.1$ & 0,768 & 0,22 & Valid \\
\cline { 2 - 5 } & $\mathrm{X} 3.2$ & 0,604 & 0,22 & Valid \\
\cline { 2 - 5 } & $\mathrm{X} 3.3$ & 0,783 & 0,22 & Valid \\
\hline \multirow{4}{*}{ Kinerja (Y) } & $\mathrm{X} 3.4$ & 0,767 & 0,22 & Valid \\
\cline { 2 - 5 } & $\mathrm{Y} .1$ & 0,691 & 0,22 & Valid \\
\cline { 2 - 5 } & $\mathrm{Y} .2$ & 0,75 & 0,22 & Valid \\
\cline { 2 - 5 } & $\mathrm{Y} .3$ & 0,674 & 0,22 & Valid \\
\cline { 2 - 5 } & $\mathrm{Y} .4$ & 0,566 & 0,22 & Valid \\
\cline { 2 - 5 } & $\mathrm{Y} .5$ & 0,613 & 0,22 & Valid \\
\cline { 2 - 5 } & $\mathrm{Y} .6$ & 0,68 & 0,22 & Valid \\
\hline & $\mathrm{P}$ & & & \\
\hline
\end{tabular}

Sumber: Data Penelitian Diolah (2019)

$$
\text { Berdasarkan hasil uji }
$$

validitas nilai $r$ hitung seluruh butir pernyataan pengujian uji validitas lebih besar dari nilai $r$ tabel $(\mathrm{N}-2$ atau $80-2=78$, $r$ tabel 0,220 ) dengan taraf signifikan 0,05 , maka dapat dinyatakan bahawa pengujian validitas pada masing-masing variabel dinyatakan valid.

\section{Uji Realibilitas}

\begin{tabular}{|l|c|c|c|}
\hline \multicolumn{1}{|c|}{ Variabel } & $\begin{array}{c}\text { Cronbach' } \\
\text { s Alpha }\end{array}$ & $\begin{array}{c}\text { Koefisien } \\
\text { Realibilitas }\end{array}$ & Keterangan \\
\hline Kepribadian (X1) & 0,687 & 0,60 & Reliabel \\
\hline Orientasi Kerja (X2) & 0,618 & 0,60 & Reliabel \\
\hline Penempatan (X3) & 0,711 & 0,60 & Reliabel \\
\hline Kinerja (Y) & 0,742 & 0,60 & Reliabel \\
\hline
\end{tabular}

Sumber: Data Penelitian Diolah (2019)

Berdasarkan hasil penelitian pada uji realibilitas masing- masing variabel kepribadian, orientasi kerja, penempatan dan kinerja memiliki nilai cronbach's alpha lebih besar dari 0,60. Maka dapat disimpulkan bahwa masing-masing variabel dinyatakan reliabel.

\section{Uji Normalitas}

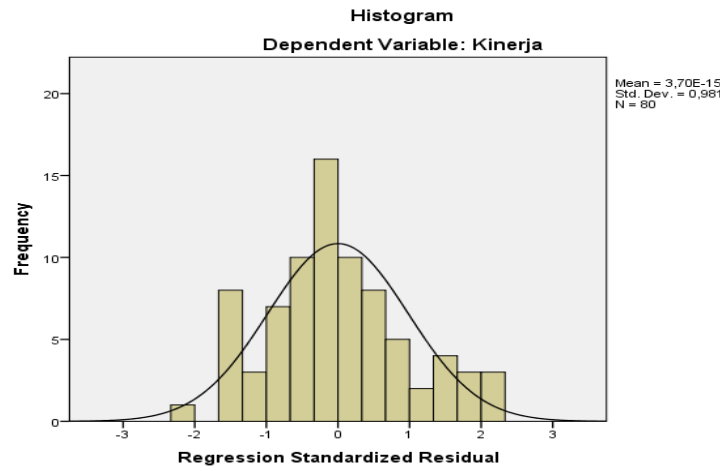

Gambar diatas menunjukkan membentuk pola gambar lonceng atau bell shaped maka dapat disimpulkan bahwa data memiliki distribusi normal (Wibowo, 2012). Cara kedua untuk menguji normalitas adalah dengan melihat gambar grafik Normal P-P plot of Regresion Standarized Residual pada gambar dibawah ini: 


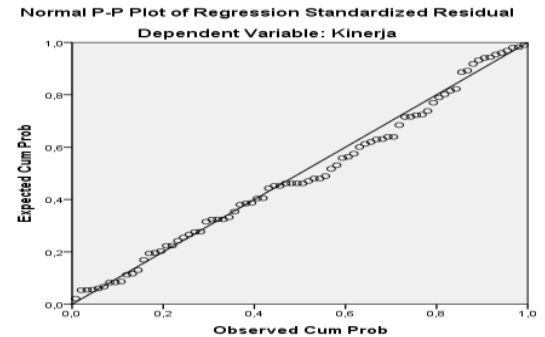

Gambar

diatas memperlihatkan ketentuan bahwa titik-titik data menyebar disekitar garis diagonal dan mengikuti arah garis diagonal maka dapat dikatakan data memenuhi asumsi normalitas.

\section{Uji Multikolinearitas}

\begin{tabular}{|c|c|c|c|c|}
\hline \multirow{2}{*}{ Model } & \multicolumn{2}{|c|}{ Collinearity } & \multirow{2}{*}{ Keterangan } \\
\cline { 2 - 4 } & Tolerance & VIF & \\
\hline 1 & Kepribadian & 0,739 & 1,353 & Tidak Terdapat Multikolinearitas \\
\cline { 2 - 4 } & Orientasi Kerja & 0,737 & 1,357 & Tidak Terdapat Multikolinearitas \\
\hline Penempatan & 0,995 & 1,005 & Tidak Terdapat Multikolinearitas \\
\hline
\end{tabular}

a. Dependent Variable: Kinerja

Hasil uji multikolinearitas menunjukkan bahwa nilai tolerance untuk variabel $\mathrm{X} 1, \mathrm{X} 2$, dan $\mathrm{X} 3$ masing-masing sebesar 0,$739 ; 0,737$ dan 0,995 dan nilai VIF untuk variabel $\mathrm{X} 1, \mathrm{X} 2$ dan $\mathrm{X} 3$ masingmasing sebesar 1,$353 ; 1,357$ dan 1,005 sehingga dapat disimpulkan bahwa dalam model regresi tidak terdapat gejala multikolinearitas antar variabel bebas karena nilai tolerance lebih besar dari 0,1 VIF nya lebih kecil dari 10 yang berarti bahwa semua variabel tersebut dinyatakan tidak terdapat gejala multikolinearitas.

\section{Uji Heterokedastisitas}

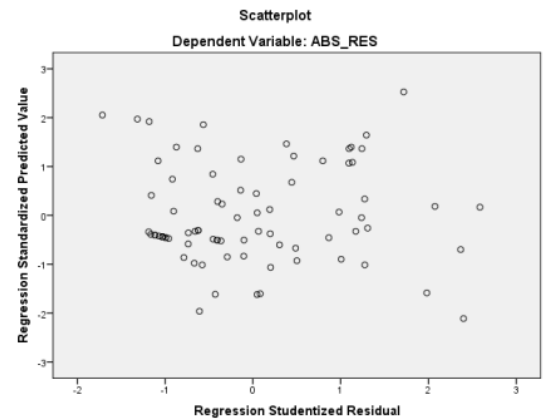

Berdasarkan pada gambar diatas menunjukkan titik-titik menyebar secara acak dan tersebut baik diatas maupun dibawah angka 0 (nol) pada sumbu Y, maka tidak terjadi heterokedastisitas pada model regresi sehingga layak dipakai untuk penelitian selanjutnya.

\section{PENGUJIAN HIPOTESIS}

\section{Uji t (Parsial)}

\begin{tabular}{|c|c|c|c|c|c|c|}
\hline & \multirow[t]{2}{*}{ Model } & \multicolumn{2}{|c|}{$\begin{array}{l}\text { Unstandardized } \\
\text { Coefficients }\end{array}$} & \multirow{2}{*}{\begin{tabular}{|c}
$\begin{array}{c}\text { Standardized } \\
\text { Coefficients }\end{array}$ \\
Beta
\end{tabular}} & \multirow[t]{2}{*}{$\mathrm{T}$} & \multirow[t]{2}{*}{ Sig. } \\
\hline & & B & Std. Error & & & \\
\hline \multirow{4}{*}{1} & (Constant) & $-0,219$ & 0,282 & & $-0,774$ & 0,441 \\
\hline & Kepribadian & 0,671 & 0,054 & 0,684 & 12,393 & 0,000 \\
\hline & Orientasi Kerja & 0,371 & 0,059 & 0,347 & 6,282 & 0,000 \\
\hline & Penempatan & 0,014 & 0,035 & 0,019 & 0,402 & 0,689 \\
\hline
\end{tabular}

\section{Hipotesis 1}

Berdasarkan hasil penelitian menunjukkan bahwa variabel kepribadian (X1) menunjukkan nilai signifikan $0,000<0,05$ dan t hitung $(12,393)$ lebih besar dari $\mathrm{t}$ tabel (1,991). Sehingga keputusan yang diambil adalah $\mathrm{H}_{\mathrm{o}}$ ditolak dan $\mathrm{H}_{\mathrm{a}}$ diterima. Hal ini berarti H1 (hipotesis 1) diterima yang artinya bahwa variabel kepribadian $\left(\mathrm{X}_{1}\right)$ berpengaruh terhadap kinerja karyawan (Y) di PT. Advantage Supply Chain Management (SCM) Batam. 


\section{Hipotesis 2}

Berdasarkan hasil penelitian menunjukkan bahawa variabel orientasi kerja (X2) menunjukkan nilai signifikan $0,000<0,05$ dan nilai t hitung $(6,282)$ lebih besar dari t tabel $(1,991)$ sehingga keputusan yang diambil adalah $\mathrm{H}_{\mathrm{o}}$ ditolak dan $\mathrm{H}_{\mathrm{a}}$ diterima. Hal ini berarti $\mathrm{H} 2$ (hipotesis 2) diterima yang artinya bahwa variabel orientasi kerja $\left(\mathrm{X}_{2}\right)$ berpengaruh terhadap kinerja karyawan (Y) di PT. Advantage Supply Chain Management (SCM) Batam.

\section{Hipotesis 3}

Berdasarkan hasil penelitian
menunjukkan bahawa variabel
penempatan pegawai $(\mathrm{X} 3)$
menunjukkan nilai signifikan $0,689>$
0,05 dan nilai t hitung $(0,402)$ lebih
kecil dari t tabel (1,991) sehingga
keputusan yang diambil adalah $\mathrm{H}_{\mathrm{o}}$
diterima dan $\mathrm{H}_{\mathrm{a}}$ ditolak. Hal ini
berarti $\mathrm{H3}$ (hipotesis 3) ditolak yang
artinya bahwa variabel penempatan
pegawai (X) tidak berpengaruh
terhadap kinerja karyawan (Y) di PT.
Advantage Supply
Management (SCM) Batam.

Uji F (Simultan)

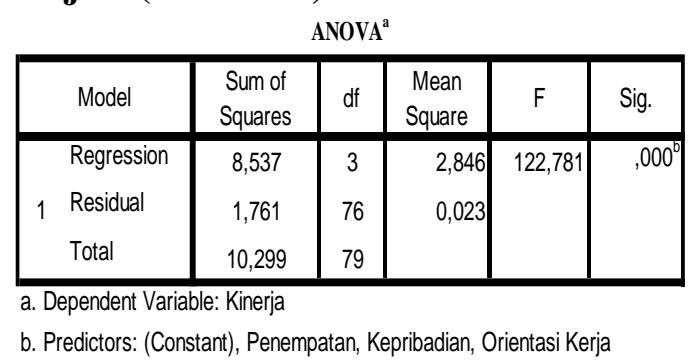

\section{Hipotesis 4}

Berdasarkan hasil penelitian menunjukkan hasil uji $\mathrm{F}$ yaitu nilai probabilitas signifikansi sebesar $0,000<0,05$ dan nilai $F$ hitung
$(122,781)$ lebih besar dari $\mathrm{F}$ tabel $(2,72)$, sehingga keputusan yang diambil adalah $\mathrm{H}_{\mathrm{o}}$ ditolak dan $\mathrm{H}_{\mathrm{a}}$ diterima. Hasil ini $\mathrm{H} 4$ (hipotesis 4) diterima yang artinya menunjukkan bahwa variabel kepribadian $\left(\mathrm{X}_{1}\right)$, orientasi kerja $\left(\mathrm{X}_{2}\right)$ dan penempatan pegawai $\left(\mathrm{X}_{3}\right)$ secara bersama-sama berpengaruh terhadap kinerja karyawan (Y) di PT. Advantage Supply Chain Management (SCM) Cabang Batam.

\section{KESIMPULAN}

Berdasarkan hasil penelitian dan pembahasan yang telah dilakukan pada bab sebelumnya, maka dapat disimpulkan bahwa:

1. Pengujian hipotesis untuk variabel kepribadian (X1) menunjukkan nilai signifikan $0,000<0,05$ dan nilai $t$ hitung sebesar 12,393 > t tabel 1,991. Sehingga hasil penelitian menunjukkan variabel kepribadian (X1) berpengaruh signifikan terhadap kinerja karyawan.

2. Pengujian hipotesis untuk variabel orientasi kerja (X2) menunjukkan nilai signifikan $0,000<0,05$ dan nilai t hitung sebesar 6,282 > t tabel 1,991. Sehingga hasil penelitian menunjukkan variabel orientasi kerja (X2) berpengaruh signifikan terhadap kinerja karyawan.

3. Pengujian hipotesis untuk variabel penempatan pegawai (X3) menunjukkan nilai signifikan 0,689>0,05 dan nilai $\mathrm{t}$ hitung sebesar $0,402<\mathrm{t}$ tabel 1,991. Sehingga hasil penelitian menunjukkan variabel penempatan pegawai (X3) 
berpengaruh dan tidak signifikan terhadap kinerja karyawan.

4. Hasil pengujian uji $F$ memperlihatkan nilai probabilitas signifikansi sebesar $0,000<0,05$ dan $F$ hitung $122,781>$ atau lebih besar dari $\mathrm{F}$ tabel 2,72, sehingga keputusan yang diambil variabel kepribadian, orientasi kerja, dan penempatan pegawai secara bersama-sama berpengaruh terhadap kinerja karyawan PT. Advantage Supply Chain Management (SCM) Cabang Batam.

\section{SARAN}

Berdasarkan hasil penelitian ini, beberapa saran atau rekomendasi yang dapat diberikan kepada perusahaan maupun untuk penelitian yang akan datang sebagai berikut:

1. Hasil penelitian yang dilakukan oleh peneliti dapat menjadi bahan pertimbangan untuk PT. Advantage Supply Chain Management (SCM) Cabang Batam dalam melakukan pengambilan keputusan terkait dengan masalah kepribadian, orientasi kerja dan penempatan pegawai.

2. Hasil penelitian menunjukkan bahwa kepribadian dan orientasi kerja sudah berjalan dengan baik, akan tetapi penempatan pegawai belum berjalan dengan baik untuk itu PT. Advantage Supply Chaim Management (SCM) Cabang Batam sebaiknya memperbaiki penempatan pegawai sehingga kinerja karyawan dapat meningkat dengan baik.

3. Hasil penelitian ini dapat digunakan oleh peneliti yang lain sebagai bahan pertimbangan untuk pengembangan ilmu pengetahuan Manajemen Sumber Daya Manusia khususnya dibidang Kepribadian, Orientasi kerja dan Penempatan pegawai terhadap Kinerja Karyawan.

4. Penelitian selanjutnya diharapkan agar bisa menambah variabel, indikator, ruang lingkup maupun jumlah pernyataan kuesioner agar penelitian bisa lebih dikembangkan dan memberikan hasil penelitian yang lebih maksimal.

\section{KETERBATASAN PENELITIAN}

Adapun keterbatasan dalam penelitian ini adalah sebagai berikut :

1. Jumlah responden yang relatif sedikit yaitu 80 responden atau karyawan PT. Advantage Supply Chain Management (SCM) Cabang

2. Butir - butir pernyataan tidak semua indikator permasalahan dibahas, dalam kinerja karyawan ada beberapa faktor yang mempengaruhinya.

3. Waktu penyebaran kuisioner sangat terbatas, sehingga dalam pengisian kuisioner terburu-buru dan tidak terbuka.

\section{DAFTAR PUSTAKA}

Akbar, Rahman. (2018). Pengaruh Penempatan dan Pengalaman Kerja Terhadap Prestasi Kerja (Studi Pada Pegawai Dinas Pekerjaan Umum Kabupaten Buton). Skripsi Fakultas Ekonomi dan Bisnis Islam IAIN Alauddin Makasar. Diakses tanggal 24 Oktober 2018. 
Alfian, Yuda, Mochammad Al Musadieq dan M. Cahyo Widyo Sulistyo. (2018). Pengaruh Kepribadian dan Kompetensi Terhadap Kinerja Karyawan (Studi Karyawan PT PLN (Persero) Area Pasuruan. Jurnal Administrasi Bisnis (JAB) Vol. 58 No. 2 Mei 2018. Diakses tanggal 09 Januari 2019.

Ardana, I Komang, Mujiati dan Utama. (2012). Manajemen Sumber Daya Manusia. Yogyakarta: Graha Ilmu.

Arikunto, Suharsimi. (2013). Prosedur Penelitian: Suatu Pendekatan Praktik. Jakarta: Rineka Cipata.

Astuti, Maya Dwi, Andri Tri Haryono dan M Murkery Warso. (2017). Analisis Pengaruh Rekrutmen, Kemampuan, Kepribadian, Motivasi, Komitmen Terhadap Kinerja SDM Pada PT Bina Jasa Sumber Sarana. Program Studi Manajemen Fakultas Ekonomi. Diakses tanggal 24 Oktober 2018.

Bangun, Wilson. (2012). Manajemen Sumber Daya Manusia.Bandung: Erlangga.

Danang, Sunyoto. (2012). Manajemen Sumber Daya Manusia. Jakarta: PT. Buku Seru.

Effendy, Evi Salwia. (2017). Pengaruh Penempatan Kerja Terhadap Kinerja Pegawai Pada Kantor Kejaksaan Negeri Kendari. Skripsi Manajemen Fakultas Ekonomi Universitas Halu Oleo. Diakses tanggal 24 Oktober 2018.
Ghozali, Imam. (2013). Aplikasi Analisis Multivariate dengan Program SPSS. Edisi ketujuh. Semarang: Badan Penerbit Universitas Diponegoro.

Hertanudin. (2015). Pengaruh Budaya Organisasi dan Penempatan Kerja Serta Pengawasan terhadap Kinerja Pegawai PDAM Lematang Enim Cabang Tanjung Ennim. Jurnal Manajemen Vol.5 No.1 Desember 2015.Diakses tanggal 24 Oktober 2018.

Marwansyah. (2009). Manajemen Sumber Daya Manusia. Bandung: Alfabeta

Meigantri, Ni Luh Gede Yuanda dan I Gusti Salit Ketut Netra.(2016). Pengaruh Penempatan, Keadilan Organisasional, Kepuasan Kerja Terhadap Kinerja Pegawai RSUD Wangaya Kota Denpasar. E-Jurnal Manajemen Unud, ISSN : 2302-8912 Vol. 5 No.1, 2016: 3986-4015. Diakses tanggal 24 Oktober 2018.

Montolalu, Ricky, Lotje Kawet dan Nelwan. (2016). Pengaruh Kepribadian, Orientasi Kerja dan Penempatan Pegawai Terhadap Kinerja Pegawai Pada Dinas Kebudayaan dan Pariwisata Provinsi Sulawesi Utara. Jurnal EMBA ISSN 2303-1174 Vol.4 No.1 Maret 2016.Diakses tanggal 24 Oktober 2018.

Muaja, Karina Octavia, Adolfina dan Lucky O.H Dotulong. Pengaruh Penempatan Kerja dan Pengalaman Kerja Terhadap Kinerja Kerja Karyawan Pada PT. Bank 
Sulutgo Kantor Cabang Utama Manado.(2017). Jurnal EMBA Vol. 05 No. 2 Juni 2017. Diakses tanggal 10 Januari 2019.

Pratiwi, Putu Anggita Laksmi, Victor P.K Lengkong dan Christoffel M.O Mintardjo. (2017). Pengaruh Orientasi Kerja dan Budaya Organisasi Terhadap Kinerja Karyawan (Studi Pada PT. PLN Persero Wilayah Sulut Tenggo Area Manado). Journal Riset Ekonomi, Manajemen Bisnis dan Akutansi. Jurnal EMB A, ISSN 2303-1174, Vol. 5 No. 2 Juni 2017. Diakses tanggal 06 November 2018.

Rahadi, Dedi Rianto. (2010). Manajemen Kinerja Sumber Daya Manusia. Malang: Tunggal Mandiri Publishing.

Rivai, Veithzal. \& Sagala, E.J. (2009). Manajemen Sumber Daya Manusia untuk Perusahaan. Jakarta: Rajagrafindo Persada.

Rudianto, Arif Bondan. (2018). Pengaruh Disiplin Kerja dan Penempatan Pegawai Terhadap Semangat Kerja Pegawai di PT. Taspen (persero) KCU Bandung. Skripsi Fakultas Ekonomi dan Bisnis Universitas Pasundan. Dikases tanggal 10 Januari 2019.

Sedarmayanti. 2010. Manajemen Sumber Daya Manusia Reformasi Birokrasi dan Manajemen Pegawai Negeri Sipil. Bandung: Refika Aditama.
Setyarini, Putri. (2017). Pengaruh Kepribadian Terhadap Kerjasama Tim Melalui Komitmen Sebagai Variabel Intervening (Studi Kasus Pada Bank Tabungan Negara Syariah Semarang). Skripsi Fakultas Ekonomi dan Bisnis Islam. Diakses tanggal 24 Oktober 2018.

Sihombing, IK. (2017). Pengembangan Kepribadian Mahasiswa Dengan Konseptual Dunia Kerja. Jakarta: Buku Pendidikan Deepublish

Smalley, Larry R. (2010). Orientasi dan Pelatihan Ditempat Kerja. Jakarta: PPM Bisnis 2030.

Sugiyono. (2015). Metode Penelitian Manajemen. Cetakan ke-4. Bandung: Alfabeta.

Wibowo, Agung Edy. (2012).Aplikasi Praktis SPSS Dalam Penelitian, -Cet 1 Yogyakarta : Gava Media.

Yanis, Billy Saputra. (2017). Pengaruh Kompetensi dan Penempatan Terhadap Semangat Kerja dan Kinerja Pegawai Dinas Pendapatan Daerah Kabupaten Bengkalis. Jurnal Tepak Manajemen Bisnis. Vol.IX No.2 Mei 2017. Diakes tanggal 24 Oktober 2018.

Yuliawati, Elis. (2015). Analisis Pengaruh Rekrutmen SDM, Kesesuaian Penempatan Karyawan dan Lingkungan Kerja Fisik Terhadap Kinerja Karyawan Produksi Weaving (Studi Kasus Pada PT. Sandratex Ciputat-Tangerang Selatan). Skripsi Fakultas 
Ekonomi Bisnis Universitas

Islam Negeri Syarif

Hidayatullah. Diakses tanggal

24 Oktober 2018. 